\title{
Angiogenesis inhibition by green propolis and the angiogenic effect of $L$-lysine on bladder cancer in rats $^{1}$
}

\author{
Inibição da angiogênese pela própolis verde e efeito angiogênico \\ da $L$-lisina no câncer de bexiga em ratos
}

\begin{abstract}
Conceição Aparecida Dornelasi, Francisco Vagnaldo Fechine-Jamacaru ${ }^{\mathrm{II}}$, Irineu Lima Albuquerque ${ }^{\mathrm{III}}$, Hemerson Iury

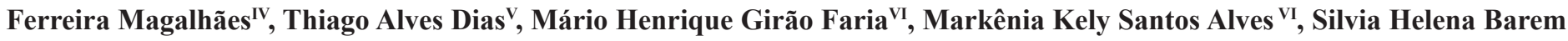
Rabenhorst $^{\mathrm{VII}}$, Paulo Roberto Carvalho de Almeida ${ }^{\mathrm{VIII}}$, Telma Leda Gomes de Lemos ${ }^{\mathrm{IX}}$, José Daniel Vieira de Castro ${ }^{\mathrm{X}}$, Maria Elisabete Amaral Moraes ${ }^{\mathrm{XI}}$, Manoel Odorico Moraes ${ }^{\mathrm{XII}}$
\end{abstract}

IPhD, Associate Professor, Department of Pathology, UFC, Ceara, Brazil Responsible for conception, design, scientific content, manuscript writing. IIPhD, Visiting Professor, Department of Physiology and Pharmacology, UFC, Ceara, Brazil. Responsible for interpretation of data and statistical analysis.

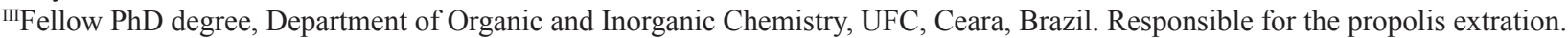

${ }^{\mathrm{IV}}$ Fellow PhD degree, Department of Physiology and Pharmacology, UFC, Ceara, Brazil. Responsible guidance and monitoring in weighing and dilution of the products used in the experiment.

${ }^{\mathrm{v}}$ Graduate student, Department of Physiology and Pharmacology, UFC, Ceara, Brazil. Animal care and treatments.

${ }^{\mathrm{VI}}$ Fellow PhD degree, Department of Pathology, UFC, Ceara, Brazil. Immunohistochemical technique.

VIIPhD, Associate Professor, Department of Pathology, UFC, Ceara, Brazil. Supervision immunohistochemical technique.

${ }^{\mathrm{VIII}} \mathrm{PhD}$, Associate Professor, Department of Pathology, UFC, Ceara, Brazil. Histological analyses.

${ }^{\mathrm{Ix}} \mathrm{PhD}$, Associate Professor, Department of Organic and Inorganic Chemistry, UFC, Ceara, Brazil. Supervision throughout the procedure to extract the propolis.

xPhD, Associate Professor, Department of Radiology, UFC, Ceara, Brazil. Responsible for the ultrasound images.

${ }^{\mathrm{X}} \mathrm{PhD}$, Associate Professor, Department of Physiology and Pharmacology, UFC, Ceara, Brazil. Critical revision.

${ }^{\mathrm{XII} C h a i r m a n, ~ D e p a r t m e n t ~ o f ~ P h y s i o l o g y ~ a n d ~ P h a r m a c o l o g y, ~ U F C, ~ C e a r a, ~ B r a z i l . ~ S u p e r v i s i o n ~ o f ~ a l l ~ p h a s e s ~ o f ~ t h e ~ s t u d y . ~}$

\section{ABSTRACT}

PURPOSE: To determine the effects of water-soluble derivative of green propolis in bladder cancer angiogenesis in rats given N-butyl(-4-hydroxybutyl) nitrosamine (BBN).

METHODS: Nine groups were established, where six of them (Groups 1 to 6), the animals received 0.05\% BBN in their drinking water for 14 weeks. From the 32nd to the 40th week, Groups 1, 2, 3 and 4 were treated respectively with water, $L$-lysine (300 mg/kg/ day), celecoxib (30 mg/kg/day) and propolis (300 mg/kg/day). Groups 5 and 6 were given propolis and $L$-lysine from the $1 \mathrm{st}$ to the 40 th week (150 mg/kg/day). Microvascular density was determined by histological sections stained for the marker CD-31 and analyzed with specific software.

RESULTS: The microvascular density in bladder carcinomas was lower $(\mathrm{p}<0.01)$ in rats receiving propolis than in controls given carcinogen only. On the other hand, the microvascular density of tumors in rats receiving carcinogen and $L$-lysine for 40 weeks from the beginning of carcinogen treatment was significantly higher $(\mathrm{p}<0.01)$ than in the corresponding controls.

CONCLUSION: Water-soluble derivative of propolis inhibits angiogenesis in BBN-induced rat bladder cancer, while $L$-lysine treatment stimulates angiogenesis if initiated concurrently with BBN.

Key words: Lysine. Propolis. Angiogenesis Inhibitors. Urogenital Neoplasms. Rats.

\section{RESUMO}

OBJETIVO: Determinar os efeitos da própolis verde solúvel em água na angiogênese de câncer de bexiga em ratos que receberam n-butil-(-4-hidroxibutil) nitrosamina (BBN).

METODOS: Nove grupos foram estabelecidos, onde em seis destes (grupos de 1 a 6 ) os animais receberam BBN a 0,05\% em água 
de beber por 14 semanas. $\mathrm{Na} 32^{\mathrm{a}}$ semana das 40 semanas, os grupos 1, 2, 3 e 4 foram tratados respectivamente com água, $L$ lisina (300 $\mathrm{mg} / \mathrm{kg} / \mathrm{dia})$, celecoxibe $(30 \mathrm{mg} / \mathrm{kg} / \mathrm{dia})$ e própolis $(300 \mathrm{mg} / \mathrm{kg} / \mathrm{dia})$. Os grupos 5 e 6 receberam própolis e $L$ lisina da $1^{\mathrm{a}}$ a $40^{\mathrm{a}}$ semana $(150 \mathrm{mg} / \mathrm{kg} / \mathrm{dia})$. A densidade microvascular foi determinada por cortes histológicos corados pelo CD-31 e analisados por programa de computador específico.

RESULTADOS: A densidade microvascular em carcinomas de bexiga foi menor com $\mathrm{p}<0,01$ nos ratos que receberam própolis do que nos carcinomas do grupo controle que recebeu apenas carcinógeno. Por outro lado, a densidade microvascular de tumores de ratos que receberam carcinógeno e $L$-Lisina por 40 semanas desde o início do carcinógeno foi significantemente maior com p $<0,01$ que a densidade microvascular dos tumores de seu respectivo grupo controle.

CONCLUSÃO: A própolis verde solúvel em água inibiu a angiogênese em câncer de bexiga induzido pelo BBN, enquanto a $L$ - lisina estimulou a angiogênese quando iniciada juntamente com o BBN.

Descritores: Lisina. Própole. Inibidores da Angiogênese. Neoplasias Urogenitais. Ratos.

\section{Introduction}

Angiogenesis is a physiological or physiopathological process involving the growth of new blood microvessels from preexisting capillaries ${ }^{1}$, induced by a range of chemical factors, some of which are related to genetic changes, termed angiogenic and antiangiogenic factors.

Propolis is a resinous substance that honey bees collect from botanical sources and mix with their own saliva. It is used as a sealant for unwanted open spaces and protects the hive against microorganisms. Green propolis is found in Southeastern Brazil and is so called because of the presence of green pigment collected from the shrub species Baccharis dracunculifolia.

Water-soluble derivative of propolis (WSDP) is produced by extracting soluble propolis in water using $8 \% \mathrm{~L}$-lysine ${ }^{2}$. $L$-Lysine is a strictly essential amino acid required for collagen synthesis, tissue growth and repair, and production of antibodies, hormones and enzymes. Patented by Nicolov, the process uses $L$-lysine to extract propolis, making it possible to obtain a range of compounds with pharmacological action in a practical, watersoluble form.

Researchers have reported anti-infectious ${ }^{3}$, antiinflammatory ${ }^{4}$, immunomodulatory ${ }^{5,6}$, antitumor ${ }^{7}$, antioxidant ${ }^{8-10}$ and antimetastatic ${ }^{5}$ effects of WSDP. The discovery of the anticarcinogenic effects of propolis encouraged efforts to identify, isolate and synthesize constituents of propolis and to study their effects and mechanisms of action, including artepillin $\mathrm{C}^{11}$, caffeic acid $^{12}$, caffeic acid phenethyl ester ${ }^{13}$, and in the present study, we used an in vivo model to evaluate the effect of intragastric administration of green propolis (in the form of WSDP) on angiogenesis in $\mathrm{BBN}$-induced rat bladder cancer.

\section{Methods}

The experiment was previously approved by the Ethics Committee for Animal Research under protocol \# 03/06 and was carried out in accordance with the guidelines of the Animal Testing.

The study used 92 five-week-old female Wistar rats accommodated in polyethylene cages ( 5 or 6 per cage) at $22^{\circ} \mathrm{C}$ with a 12/12-hour circadian cycle. The animals had access to food (Biobase ${ }^{\circledR}$ pelleted ration) and water ad libitum.

\section{Experimental procedures}

The exclusion criteria were presence of carcinoma with extensive necrosis, autolysis or failure to develop carcinoma. The analysis included 49 animals. Microvascular density was determined for 31 (six animals from Group 1 and five animals from each of Groups 2, 3, 4, 5 and 6). See experimental design Figure 1.

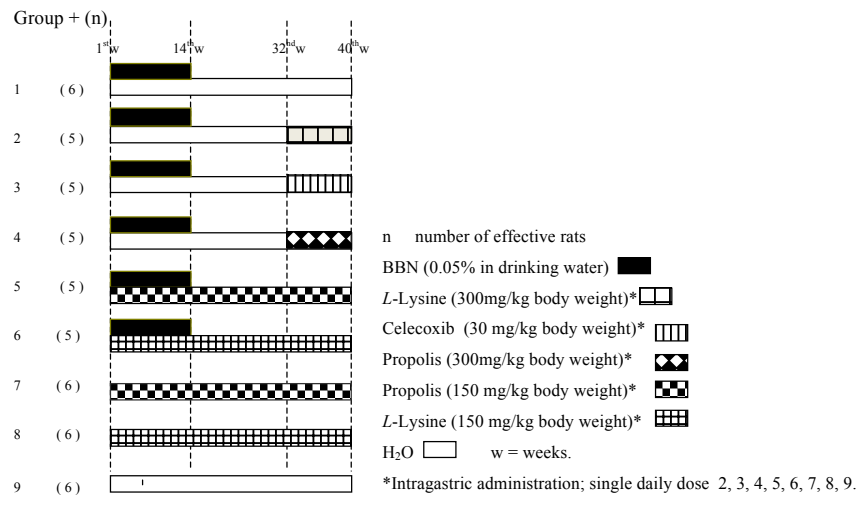

FIGURE 1 - Design of the experiment. 


\section{N-butyl-N-[4-hydroxybutyl] nitrosamine}

BBN was purchased from TCI America (Portland, OR). The chemical formula is $\mathrm{CH}_{3}\left(\mathrm{CH}_{2}\right)_{3} \mathrm{~N}\left[\left(\mathrm{CH}_{2}\right)_{4} \mathrm{OH}\right]$ (Chemical Abstract Service \#3817-11-6). The product was stored at $4{ }^{\circ} \mathrm{C}$. A $0.05 \%$ concentration of BBN was dissolved in water and was supplied ad libitum for 14 weeks in dark bottlers.

\section{Biosafety norms}

The laboratory animal facility and the handling of animals and materials followed WHO guidelines for use of nitrosamines in experimental research ${ }^{14,15}$ and MSDS (Material Safety Data Sheet) specifications.

\section{Water-soluble derivative of propolis (WSDP)}

Green propolis was collected from hives in Passa Quatro, Southern Minas Gerais (Brazil), from September to October. WSDP was prepared following the procedures described by Nicolov et al. ${ }^{2}$ with slight modifications. Propolis was extracted in ethyl alcohol three times, concentrated in a water bath, submitted to liquid-liquid partitioning with petroleum ether and, subsequently, with ethyl ether, and then again concentrated in a water bath. The extract was added to an $8 \% \mathrm{~L}$-lysine solution at $51-60^{\circ} \mathrm{C}$ in a proportion of $100 \mathrm{~g}$ propolis to $1500 \mathrm{ml} L$-lysine solution. The $L$-lysine-based extract was lyophilized and cold-stored in small sterilized vials appropriate for administration of 150 or $300 \mathrm{mg} / \mathrm{kg}$ body weight (Figure 2).

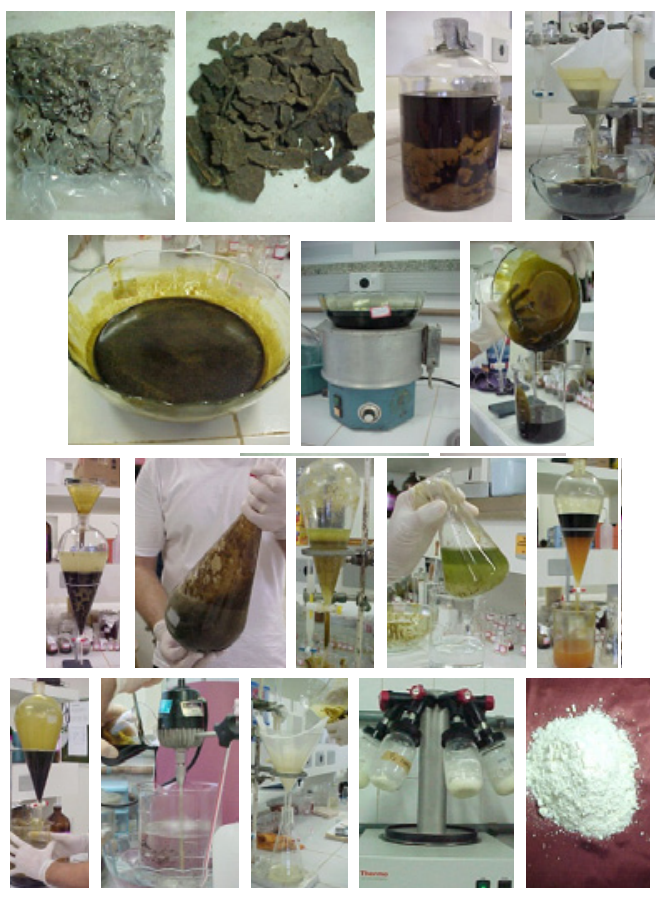

FIGURE 2 - Extraction of propolis (sequence of method of extraction of Water-Soluble Derivative of Propolis).

\section{Antioxidant activities}

The freeze-dried propolis WSDP and the ethanol extract of propolis in natura in concentrations of 1000, 250 and $62.5 \mathrm{ppm}$ were evaluated for DPPH (1,1-diphenyl-2picrylhydrazyl) radical scavenging activities and compared with the controls for vitamin $\mathrm{C}$ and Trolox (a water-soluble derivative of vitamin E).

\section{$\underline{\text { L-Lysine }}$}

The amino acid $L$-lysine monohydrochloride $\left(\mathrm{C}_{6} \mathrm{H}_{14} \mathrm{~N}_{2} \mathrm{O}_{2} \cdot \mathrm{HCl}\right.$; CAS \#657-27-2) was prepared for extraction in a distilled water solution at $8 \%$ and administered at doses of 150 and $300 \mathrm{mg} / \mathrm{kg}$. Celecoxib was administered orally as a positive control at a dose of $30 \mathrm{mg} / \mathrm{kg}$ body weight.

\section{Ultrasound scanning}

At 31 and 40 weeks, all animals were anesthetized peritoneally with $80 \mathrm{mg} / \mathrm{kg}$ ketamine and $8 \mathrm{mg} / \mathrm{kg}$ xylazine and submitted to ultrasound scanning of the bladder in transversal and sagittal sections using a 12-MHz linear transducer $\left(\mathrm{Philips}^{\circledR}\right)$.

\section{Immunohistochemistry}

Histological 5- $\mu \mathrm{m}$ sections of bladder tumors were placed on slides coated with organosilane (3-aminopropyltriethoxysilane/SIGMA). Following deparaffination and hydration, antigen retrieval was performed with $1 \mathrm{mM}$ ethylenediamine tetraacetic acid (EDTA) at $\mathrm{pH} 8$ in a pressure cooker for 8 minutes. Endogenous peroxidase activity was blocked with $3 \% \mathrm{H}_{2} \mathrm{O}_{2}$ for 10 minutes. Samples were incubated overnight in a moist chamber at $4^{\circ} \mathrm{C}$ with primary antibody PECAM-1 (M20): sc-1506 (Santa Cruz Biotechnology, Inc.) diluted to 1:50. Subsequently, samples were rinsed with phosphate buffer saline (PBS) and incubated with secondary biotinylated swine antigoat/rabbit/mouse antibody (yellow reagent in the streptavidinbiotin kit; LSAB kit/HRP by Dako) in a moist chamber at room temperature for 30 minutes. Samples were again rinsed in PBS for 1 minute followed by incubation for 30 minutes with red streptovidin+peroxidase reagent. The reaction was revealed using $10 \%$ 3.3'- diaminobenzidine tetrahydrochloride (DAB) and hydrogen peroxide, and then counterstained with Carazzi's hematoxylin.

\section{Image acquisition and quantification of angiogenesis}

Images of histological samples were acquired in standard fashion using a light microscope (BX4, Olympus Optical Co. Ltd., 
Japan) fitted with a digital camera (C7070 Wide Zoom, Olympus Imaging America Inc., USA). The procedure included an initial scan of the tumor at $40 \mathrm{X}$ magnification in order to identify areas with increased vascular density (hot spots) ${ }^{16}$. Three hot spots selected for each tumor were then color-scanned at 200x magnification. Images were saved as Windows ${ }^{\circledR}$ bitmaps measuring 512 x 384 pixels ( 1 pixel $=24$ bits, RGB color scheme). Images were processed with a morphometric analysis software developed specifically for this purpose ${ }^{17}$. The system was previously adjusted to the color spectrum produced by the staining techniques employed. This step enabled the software to automatically identify and segment (single out) blood microvessels in both full images and user-defined regions. However, interactive segmentation (making changes in segmentation parameters) remained an option whenever the automatic mode was deemed inadequate. Following segmentation, the software provided the microvascular density of areas of interest (Figure 3). The area density was calculated by dividing the area of microvasculature by the total area analyzed.

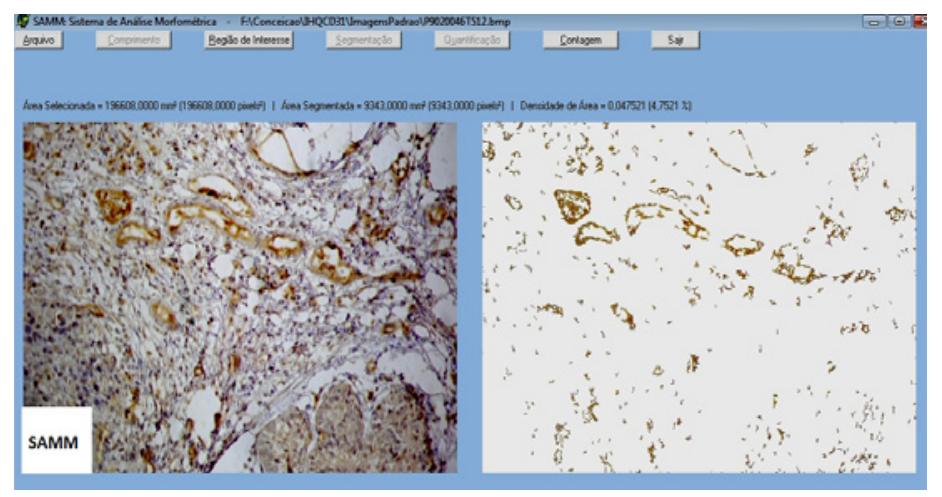

FIGURE 3 - Identification and segmentation of vessels and cells immunostained with calculation of microvessel density: total area occupied by microvessels divided by the total area of the field analyzed.

\section{Descriptive statistics}

The quantitative variables were initially analyzed with the Kolmogorov-Smirnov pretest to verify the normality of distribution. Having observed normality in all cases, means and standard deviations were calculated for the descriptive statistics, and the data were analyzed with parametric tests. Pairwise comparisons were made between groups with one-way analysis of variance combined with Tukey's multiple comparison test ${ }^{18}$. In all cases, the $\alpha$-probability of a type-I error was established as 0.05 (5\%). Thus, two-tailed p-values less than 0.05 were considered statistically significant. Statistics and preparation of figures were carried out with the help of the software GraphPad Prism ${ }^{\circledR}$ v. 5.00 for Windows ${ }^{\circledR}$ (GraphPad Software, San Diego, CA, USA, 2007).

\section{Results}

Characterization of propolis

The lyophilized propolis was submitted to highperformance liquid chromatography (HPLC) and quantified (Table 1, Figure 4).

TABLE 1 - Quantification of markers identified in the lyophilizate (mg compound/g powder).

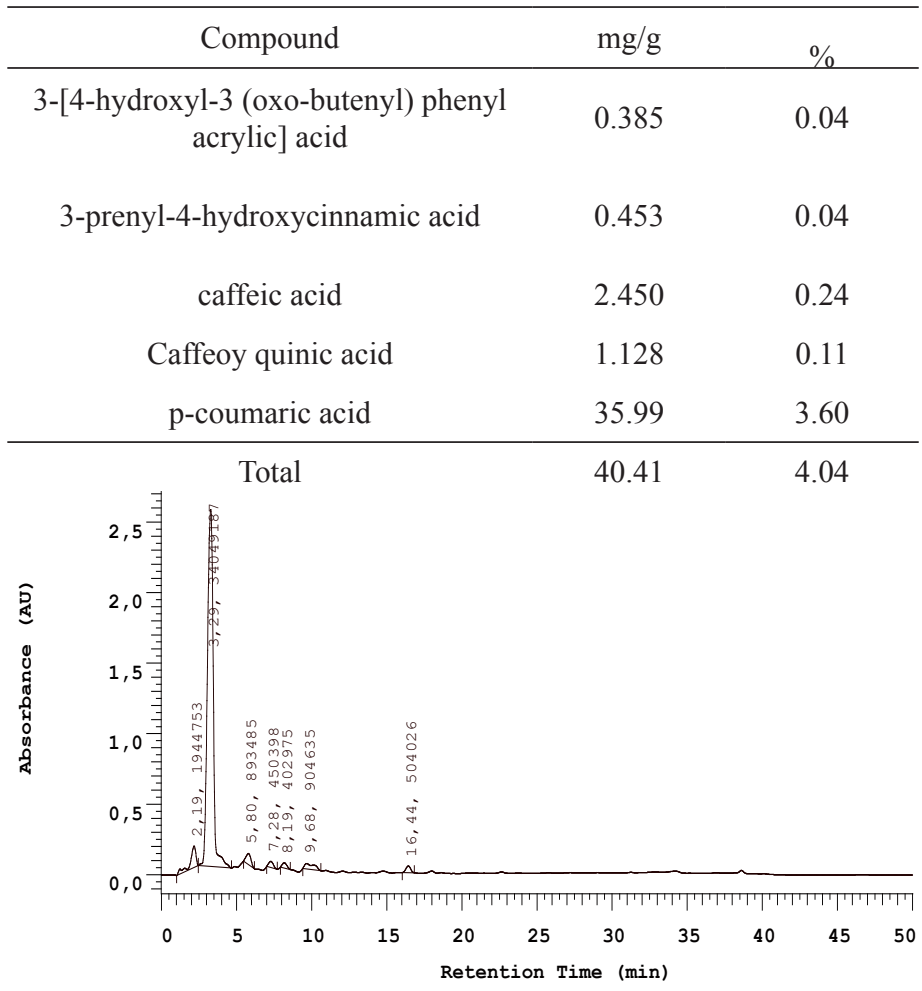

FIGURE 4 - High Performance (pressure) Liquid Chromatography (HPLC).

\section{Antioxidant activities}

DPPH radical scavenging activity of freeze-dried propolis (WSDP) and propolis ethanol extract in natura, at concentrations of 1000, 250 and $62.5 \mathrm{ppm}$ show similar values to the antioxidant activity of the controls Trolox (T) and Vitamin C (Figure 5). 


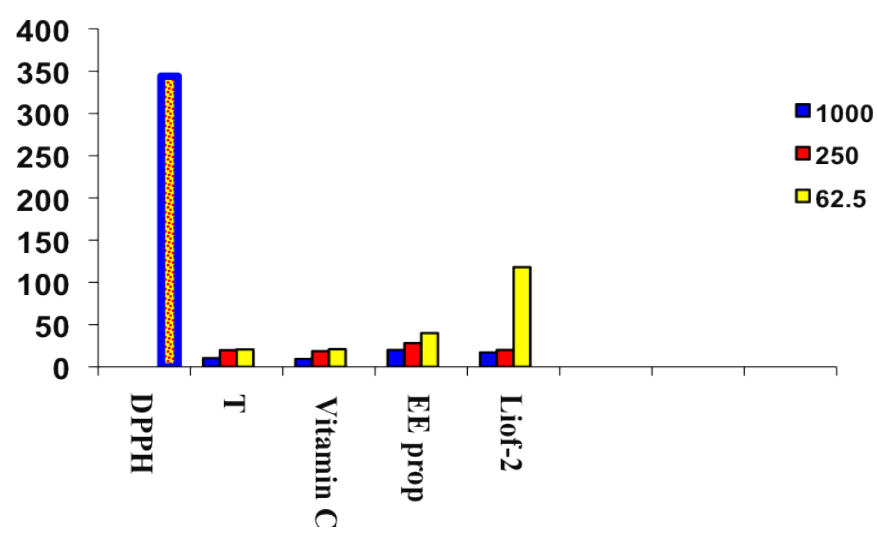

FIGURE 5 - DPPH radical scavenging activity of freeze-dried propolis Liof-2 (WSDP) and propolis ethanol extract (EE prop) in natura.

\section{Ultrasonography}

At weeks 31 and 40, tumors were identified on ultrasonographic images (all groups), determining the beginning of treatment (groups 1, 2, 3 and 4) and tumor development (Figure 6).
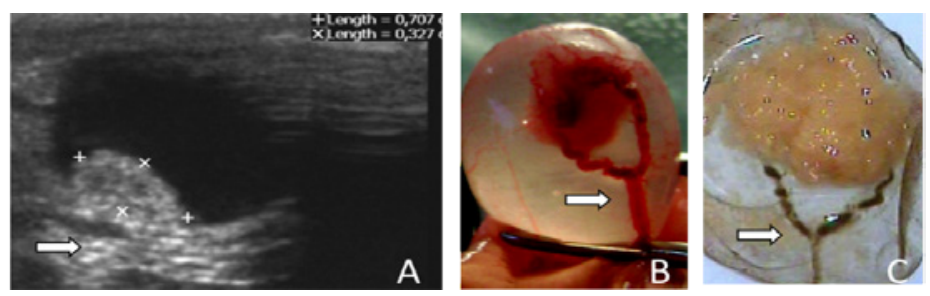

FIGURE 6 - A. Ultrasonography: image at week 40 showing tumor on posterior wall projecting into bladder. B. The same bladder $(1.4 \mathrm{~cm})$ transluminated in vivo showing intravesical tumor with thick and sinuous vessels adjoining. C. Open bladder with detail of cauliflower-like tumor growth in bladder wall - stereoscopic microscope - 10x.

\section{Statistical findings}

Findings were expressed as mean \pm standard deviation of triplicate measurements of six animals from Group 1 and five animals from each of Groups 2, 3, 4, 5 and 6. Pairwise comparisons were made between groups with one-way analysis of variance combined with Tukey's multiple comparison test (Figure 7).
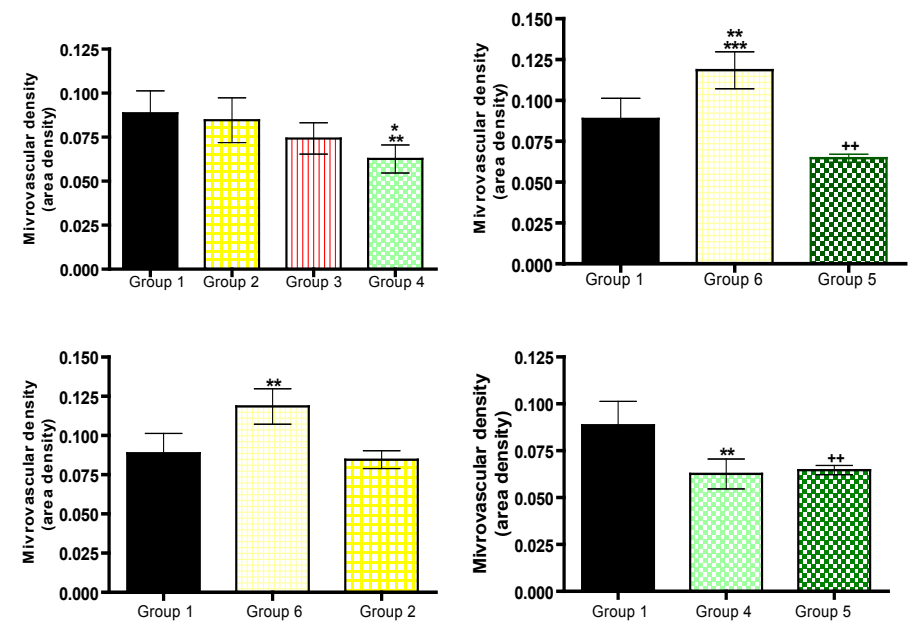

FIGURE 7 - A. Comparison of Groups 1, 2, 3 and 4 with regard to microvascular density (ANOVA and Tukey's test). The microvascular density in Group 4 was significantly smaller than that of Group $1(* * p<0.01)$ and Group $2(* \mathrm{p}<0.05)$. B. Comparison of Groups 1,6 and 5 with regard to microvascular density. The density in Group 6 was significantly greater than that of Group $1(* * p<0.01)$ and Group $5(* * * p<0.001)$. The density in Group 5 was significantly smaller than that of Group $1(++p<0.01)$. C. Comparison of Groups 1, 6 and 2 with regard to microvascular density. The density observed for Group 6 was significantly greater $(* * \mathrm{p}<0.01)$ than that of Groups 1 and 2. D. Comparison of Groups 1, 4 and 5 with regard to microvascular density. The density observed for Group 1 was significantly greater than that of Group $4(* * p<0.01)$ and Group 5 $(++\mathrm{p}<0.01)$.

\section{Discussion}

The chemical composition of propolis is strongly dependent on the flora in the area where the hive is located, bee type, climate, temperature and season ${ }^{19,20}$.

The dose chosen for our experiment $(150 \mathrm{mg} / \mathrm{kg}$ body weight) was based on previous studies by other researchers investigating the anticarcinogenic effects of WSDP extracted from propolis collected in Minas Gerais ${ }^{5,7,8}$.

Comparisons between measures of microvascular density in Groups 1, 2, 3 and 4 show that tumor angiogenesis was significantly inhibited in Group 4 (propolis), in contrast to Group 2 (L-lysine) and Group 1 (controls receiving BBN only). Although Group 4 displayed a lower density than Group 2, there was no statistically significant difference between Group 2 and Group 1. Since Group 2 is statistically similar to Group 1 and both differ from Group 4, and considering that propolis in Group 4 was extracted with the aid of $L$-lysine, two observations may be made: propolis inhibited angiogenesis even when $L$-lysine was used in its extraction, and $L$-lysine apparently did not affect microvascular density in this tumor progression group, nor did it counteract the effect of propolis (Group 4). 
Compared to Group 1 (control), by week 40 the microvascular density was equally reduced in Group 5 and Group 4 in spite of the fact that the animals in these groups were started on WSDP at different times and doses. In other words, propolis inhibited angiogenesis regardless of whether it was administered at baseline (concurrently with BBN administration) or only later, in the tumor progression stage (starting week 32).

The findings of the present study differ from those of the first study published on antiangiogenesis induced by artepillin $\mathrm{C}$ extracted from propolis from Minas Gerais ${ }^{13}$. In that study, the ethanol extract contained $1.6 \mathrm{mg} / \mathrm{g}$ caffeic acid, $27.4 \mathrm{mg} / \mathrm{g}$ p-coumaric acid and $43.9 \mathrm{mg} / \mathrm{g}$ artepillin $\mathrm{C}$, but only the last constituent was able to inhibit tube formation in $2 \mathrm{D}$ culture of human umbilical vein epithelial cells (HUVEC). The authors also reported that propolis inhibited angiogenesis in vivo in sarcoma 180. In our study, artepillin C was not detected in WSDP, but a small amount $(0.385 \mathrm{mg} / \mathrm{g}$ WSDP $)$ of the derivate of artepillin C o 3-[4-hydroxyl-3 (oxo-butenyl) phenyl acrylic] acid. What component would then be responsible for the antiangiogenic effects observed in Groups 5 and 4 ?

In an elegant and detailed study using caffeic acid and a synthetic analog, Jung and coworkers observed inhibition of tube formation in $3 \mathrm{D}$ culture of HUVEC (in vitro) and in vivo, through the inhibition of angiogenesis in human kidney tumor implanted in nude mice ${ }^{12}$. They also reported a decrease in vascular endothelial growth factor (VEGF) and a delay in tumor growth by suppression of STAT3 phosphorylation and HIF-1 expression downregulating the production of HIF-1-mediated VEGF ${ }^{12}$.

The present findings suggest that propolis may contain compounds with antiangiogenic activity other than artepillin $\mathrm{C}^{13}$. This would partly explain why artepillin C-free lyophilized propolis inhibited angiogenesis in the present study. It has been demonstrated that a number of compounds found in propolis around the world, such as caffeic acid phenethyl ester ${ }^{11,21}$, caffeic acid $^{12}$ and artepillin $\mathrm{C}^{13}$, display antiangiogenic properties in vitro in HUVEC ${ }^{21,22}$ culture and in vivo in certain types of carcinoma. These authors demonstrated in a recent study that the ethanolic extract of Brazilian propolis suppresses the phosphorylation of ERK $1 / 2$ and inhibits tube formation in cultured HUVEC. The ethanolic extract of propolis induces the activation of caspase 3 leading to apoptosis ${ }^{23}$. Utilizing the same in vitro model, it was observed that propolis in increasing concentrations can suppress the expression of integrin $\beta 4$ and proteín P53 and reduce the action potential of the mitochondrial membrane, leading to apoptosis in the endothelial cell ${ }^{24}$.

The WSDP propolis used in this study showed strong antioxidant activity. The antioxidant effect may be responsible for the inhibitory action of angiogenesis?

Researchers investigated the angiogenic and antioxidant activities of various components from propolis: artepillin C, caffeic acid, phenethyl Ester, p- coumaric acid, galagin, apigenin, kaempferol, pinocebrin and quercetin. The effects of these components were tested on in vitro models of angiogenesis, tube formation and growth of HUVECs and antioxidants activities by DPPH. Propolis components such as caffeic acid phenethyl ester, quercetin artepillin $\mathrm{C}$, galagin and kaempferol possessed strong antiangiogenic and antioxidant activities. They found a correlation between antioxidant activity and antiangiogenic activity, and so they concluded that these components may be responsible, at last, in part, to the antiangiogenic activity of propolis ${ }^{25}$.

When comparing Groups 1, 6 and 5, the microvascular density was found to be much higher in tumors of animals started on $L$-lysine at baseline (Group 6) compared to controls (Group 1) or animals started on WSDP at baseline (Group 5), suggesting that $L$-lysine is angiogenic if administered concurrently with $\mathrm{BBN}$. This is confirmed by comparing Groups 1, 6 and 2. However, the double dose of $L$-lysine administered from week 32 on (Group 2) did not significantly affect microvascular density in relation to controls (Group 1).

Three amino acids have been described as promoting bladder cancer, namely $D L$ tryptophan, $L$-leucine and $L$-isoleucine ${ }^{26,27}$. This and the fact that WSDP is extracted with the aid of an amino acid led to the inclusion in this study of a group treated with $L$-lysine. In fact, to our knowledge, no other study on WSDP has included a control group receiving $L$ - lysine. Moreover, this is the first report of the effects of $L$-lysine on BBN-induced bladder cancer.

It is intriguing that, although the dose of $L$-lysine in Group 2 is twice that in Group 6, angiogenesis was not stimulated. Is this because the dose was different, or were the angiogenic effects observed in Group 6 due to the gene expression of a more aggressive and thus more invasive and faster-growing tumor, effects produced by $L$-lysine during initiation/promotion of carcinogenesis of the bladder epithelium? In paper accept for publication, based on the same experimental model shows that $L$-lysine was able to stimulate carcinoma multiplicity and invasion in $\mathrm{BBN}$-induced rat bladder cancer ${ }^{28}$.

Another important observation is that while the present findings indicate a significant angiogenic effect of $L$-lysine in Group 6, this effect did not overcome the inhibitory effect of propolis on angiogenesis in Group 5, although the amount of $L$-lysine in the propolis group was the same $(150 \mathrm{mg} / \mathrm{kg})$. 
Celecoxib, a selective Cox-2 inhibitor has been shown to effectively decrease tumor angiogenesis and reduce tumor growth of a variety of experimental primary tumors ${ }^{29,30}$. Celecoxib reduced microvascular density (positive control Group), but the difference was not statistically significant in relation to negative controls (Group 1).

\section{Conclusions}

Green propolis (WSDP) administered intragastrically at $150 \mathrm{mg} / \mathrm{kg}$ body weight (40 weeks) beginning concurrently with $\mathrm{BBN}$, or at $300 \mathrm{mg} / \mathrm{kg}$ beginning at week 32 of carcinogenesis, inhibits angiogenesis in $\mathrm{BBN}$-induced rat bladder cancer, and that $L$-lysine administered intragastrically at $150 \mathrm{mg} / \mathrm{kg}$ body weight (40 weeks) concurrently with BBN produces angiogenic effects in this model of bladder tumor.

\section{References}

1. Folkman J. Angiogenesis: an organizing principle for drug discovery. Nat Rev Drug Discov. 2007;6:273-86.

2. Nicolov N, Marekov N, Bancova V, Popov S, Ignatov R, Valdimirova I. Method for the preparation of water-soluble derivative of propolis. 1987; Patent no. 79903. Sofia. Bulgaria.

3. Dimov V, Ivanovska N, Manolova N, Bancova V, Nikolov N, Popov, S. Immunomodulatory action of propolis. Influence on anti-infectious protection and macrophage function. Apidologie. 1991;22:155-62.

4. Dimov V, Ivanovska N, Bankova V, Popov S. Immunomodulatory action of propolis. IV. Prophylactic activity against gram-negative infections and adjuvant effect of the water-solubble derivative. Vaccine. 1992;10:817-23.

5. Orsolic N, Basic I. Immunomodulation by water-soluble derivative of propolis: a factor of antitumor reactivity. J Ethnopharmacol. 2003;84:265-73

6. Orsolic N, KnezevicAH, Sver L, Terzic S, Basic I. Immunomodulatory and antimetastatic action of propolis and related polyphenolic compounds. J Ethnopharmacol. 2004;94:307-15.

7. Orsolic N, Kosalek I, Basic I. Synergistic antitumor effect of polyphenolic components of water soluble derivative of propolis against Ehrlich ascites tumour. Biol Pharm Bull. 2005;28:694-700.

8. Orsolic N, Terzic S, Mihaljevic Z, Sver L, Basic I. Effect of local administration of propolis and its polyphenolic compounds on tumor formation and growth. Biol Pharm Bull. 2005;28:1928-33.

9. Orsolic N, Basic I. Water-soluble derivative of propolis and its polyphenolic compounds enhance tumoricidal activity of macrophages. J Ethnopharmacol. 2005;102:37-45.

10. Orsolic N, BenkovicV, Knesevic AH, Kopjar N, Kosalec I, Bakmaz M, Mihajelvic Z, Bendelja K, Basic I. Assessment by survival analysis of the radioprotective properties of propolis and its polyphenolic compounds. Biol Pharm Bull. 2007;30:946-51.

11. Liao HF, ChenYY, Liu JJ, Hsu ML, Shieh HJ, Liao H J, Shieh CJ, Shiao MS, Chen YJ. Inhibitory effect of caffeic acid phenethyl ester on angiogenesisis, tumor invasion, and metastasis. J Agric Food Chem. 2003;51:7907-12.

12. Jung JE, Kim HS, Lee CS, Park DH, Kim Y, Lee MJ, Lee JW, Park JW, Kimm M S, Ye SK, Chung MH. Caffeic acid and its synthetic derivative CADPE, suppress tumor angiogenesis by blocking STAT3-mediated VEGF expression in human renal carcinoma cells. Carcinogenesis. 2007;8:1780-7.

13. Ahn MR, Kunimasa K, Ohta T, Kumazaw AS, Kamihira M, Kumazawa S, Kamihira M, Kaki K, Uto Y, Hori H, Nagasawa $\mathrm{H}$, Nakayama T. Suppression of tumor-induced angiogenesis by Brazilian propolis: major component artepillin $\mathrm{C}$ inhibits in vitro tube formation and endothelial cell proliferation. Cancer Lett. 2007;252:235-43.

14. Montesano R, Bartsch H, Boyland E, Della Porta G, Fishbein L, Griesemer RA, Swan AB, Tomatis L, Davis W. Handling chemical carcinogens in the laboratory problems of safety. IARC Sci Publ. 1979;33:1-32.

15. Castegnaro M, Eisenbrand G, Ellen G, Keefer L, Klein D, Sansone EB, Spincer D, Telling G, Webb K. Laboratory decontamination and destruction of carcinogens in laboratory waste: some $\mathrm{N}$ nitrosamines. IARC Sci Publ. 1982;43:1-73.

16. Weidner N. Intratumor microvessel density as a prognostic factor in cancer. Am J Pathol. 1995;147:9-19.

17. Fechine-Jamacaru FV. In vivo quantification of corneal angiogenesis using digital image processing ( $\mathrm{PhD}$ Thesis in Surgery). Federal University of Ceara: Department of Surgery; 2006.

18. Armitage P, Berry G. Statistical methods in medical research. 3ed. Oxford: Blackwell; 1994.

19. Sforcin JM, Fernandes A, Lopes CAM, Bancova V, Funari SRC. Seasonal effect on Brazilian propolis antibacterial activity. J Ethnopharmacol. 2000;73:243-9.

20. Castro ML, Cury JA, Rosalen PL, Alencar SM, Ikegaki M, Alencar SM, Ikegaki M, Duarte S, Koo, H. Própolis do sudeste e nordeste do Brasil: influência da sazonalidade na atividade antibacteriana e composição fenólica. Quim Nova. 2007;30:1512-6.

21. Song YS, Park EH, Jung KJ, Jin C. Inhibition of angiogenesis by propolis. Arch Pharmacol Res. 2002;25:500-4.

22. Chikaraishi $\mathrm{Y}$, Izuta $\mathrm{H}$, Shimazawa $\mathrm{M}$, Mishima $\mathrm{S}$, Hara $\mathrm{H}$. Angiostatic effects of Brazilian green propolis and its chemical constituents. Mol Nutr Food Res. 2010;54(4):566-75.

23. Kunimasa K, Ahn MR, Kobayashi T, Eguchi R, Kumazawa S, Fujimori Y, Nakano T, Nakayama T, Kaji K, Ohta T. Brazilian propolis suppresses angiogenesis by inducing apoptosis in tubeforming endothelial cells through inactivation of survival signal ERK1/2. Evid Based Complement Alternat Med. 2011;2011:870753. Epub 2010 Oct 31

24. Xuan H, Zhao J, Miaso J, Li Y, Chu Y, Hu F. Effect of Brazilian propolis on human umbilical vein endothelial cell apoptosis. Food Chem Toxicol. 2011;49(1):78-85.

25. Ahn MR, Kunimasa K, Kumazawa S, Nakayama T, Kaji K, Uto Y, Hori H, Nagasawa H, Ohta T. Correlation between antiangiogenic activity and antioxidant activity of various components from propolis. Mol Nutr Food Res. 2009;53:643-51.

26. Ito N, Fukushima S. Promotion of urinary bladder carcinogenesis in experimental animals. Exp Pathol. 1989;36:1-15.

27. Oliveira PA, Colaço A, De La Cruz PLF, Lopes C. Experimental bladder carcinogenesis-rodent models. Exp Oncol. 2006; 28:2-11.

28. Dornelas CA, Fechine Jamacaru FV, Albuquerquer IL Magalhães HIF, Souza AJS, Alves LA, Almeida PRC, Lemos TLG, Castro JDV, Moraes EA, Moraes MO. Chemoprevention with green propolis green propolis extracted in $\mathrm{L}$ - lysine versus carcinogenesis promotion with L-lysine in N-Butyl-N-[4-hydroxybutyl] nitrosamine (BBN) induced rat bladder cancer. Acta Cir Bras. 2012;27(2):185-92.

29. Kundu N, Fulton AM. Selective cyclooxygenase (COX)-1 or COX2 inhibitors control metastatic disease in a murine model of breast cancer. Cancer Res. 2002;62:2343-6.

30. Wand L, Chen W, Xie X, He Y, Bai X. Celecoxib inhibits tumor 
growth and angiogenesis in an orthotopic implantation tumor model of human colon cancer. Exp Oncol. 2008;30(1):42-51.

\section{Acknowledgments}

To Professor Maria Cristina Marcucci (Bandeirante University of Sao Paulo-UNIBAN) for typifying and quantifying our propolis samples and Professor Francisco Hélio Rôla from the Department of Physiology and Pharmacology at UFC Medical $\underline{\text { School for his helpful suggestions and critical comments. }}$

\section{Correspondence:}

Prof ${ }^{a}$. Conceição Aparecida Dornelas

Faculdade de Medicina

Departamento de Patologia e Medicina Legal

Caixa Postal 3169

Monsenhor Furtado, s/n

60441-750 Fortaleza - CE Brasil

Tel.: (55 85)3366-8300/3366-8301

Fax: (55 85)3366-8201

eusoucondor@yahoo.com.br

Received: March 22, 2012

Review: May 23, 2012

Accepted: June 21, 2012

Conflict of interest: none

Financial source: none

${ }^{1}$ Research performed at Laboratory of Experimental Surgery, Department of Surgery, Faculty of Medicine, Federal University of Ceara (UFC) Brazil. Part of PhD thesis, Postgraduate Program in Surgery. Tutor: Prof Manoel Odorico de Moraes. 